\title{
Soil Enzymes and Microbial Activity as Influenced by Tillage and Fertilization in Wheat Production
}

\author{
H. A. Elsoury, A.E. Shouman ${ }^{*}$ S.A.E. Abdelrazek"** and \\ H. M. Elkony \\ Research Institute of Agricultural Engineering, Agricultural \\ Research Center, "Institute of Environment Studies Research, \\ Ain Shams University and ${ }^{* *}$ Soil, Water and Environment \\ Research Institute, Agriculture Research Center, Cairo, Egypt.
}

\begin{abstract}
AIELD experiment was conducted in Burg Elarab region, Egypt, $A$ to investigate the influence of five fertilization treatments and three tillage systems on wheat productivity, soil microbial biomass and some enzymes activity. Fertilization treatments were control (without treatment) (F1), Farmyard manure (F2), Compost (F3), Mineral fertilizers (F4) and mixture of farmyard manure + compost + chemical fertilizers (F5). Tillage systems were no tillage (NT), minimum tillage (MT) and conventional tillage (CT). Experiments were designed in a split plot based on randomized complete block design (RCBD) with three replications in 2010-11 and 2011-12 growing seasons. Main plots were the tillage systems while the fertilization treatments were arranged in sub plots. The highest rate of grain yield was produced in MT system under F5 treatment. CT system showed average reduction in grain yield of about $17 \%$ than MT; while CT showed average increasing of about $4 \%$ than NT in wheat grain yield. MT and NT systems increased soil microbial biomass compared to CT. Farm yard manure or compost applications increased soil microbial biomass significantly compared with mineral fertilizer. The urease, dehydrogenase and phosphatase activities in the F4 treatment were significantly lower than in the other fertilizer treatments F2, F3, and F5. The highest value of urease activity was under NT + F2 treatment in the two years of this study.
\end{abstract}

Keywords: Tillage, Fertilization, Wheat, Microbial biomass, Enzymes activities.

Generally, intensive production system utilizing commercial fertilizer applications, pesticides and irrigation can improve the grain yield. Malhi et al. (2001) concluded that nitrogen is the most limiting nutrient in crop production and its efficient use to increase food production is more than any other input; however, much use of nitrogen may cause environmental concerns such as nitrate leaching, eutrophication, and greenhouse gases emissions and reduce crop yield. Rice et al. (2001) reported that intensive production system also can degrade soil health,enhance runoff by covering the soil with an impervious surface, contribute to surface and impurity pollution and add to production cost; 
so, alternative systems have been developed to build soil organic matter and to enhance soil health depending on renewable organic resources and minimize tillage. EL-Kouny et al. (2004), Dick (1992), Chander et al. (1998), Nishio et al. (1980), Lundquist et al. (1999), Kandeler et al. (1999), Lynch, (1983) and Mohammadi (2011) reported that fertilization is one of the soil and crop management practices, which exert a great influence on soil health, organic sources such as plant residues, farmyard manure and compost, also have a number of benefits in soil physical, chemical and biological properties through increasing soil organic matter, the number of general microorganisms and enzyme activities which resulted in enhancing soil health and crop yield production. Lal (2002) and FAO (2005) concluded that tillage is one of the major practices that reduce the organic matter level in the soil, the more a soil is tilled, the more the organic matter is broken down. Angers et al. (1993) found that even in cropping systems that return almost none of the aboveground residue back to the soil, such as silage corn production and some biofuel systems, reducing tillage intensity can result in maintaining or increasing the soil organic fraction that is most readily decomposable. Angers et al. (1993), Carter (1991), Doran (1987) reported that additionally, minimum tillage has been shown to result in increased soil microbial biomass levels before measurable changes in total soil C occur. Fan et al. (2005) showed that conventional tillage practices declined soil structure and stability over years due to depletion of soil organic matter. Mohammadi (2011) found that No tillage system increased microbial biomass carbon compared to other tillage systems. Filizola et al. (1998) and Biederbeck et al. (2005) stated that alternation to no tillage or increased cropping intensity increases microbial biomass in response to increase nutrient reserves and improved soil structure and water retention. Kandeler et al. (1999) reported that enzyme activities have been indicated as soil properties suitable for use in the evaluation of the degree of alteration of soils in both natural and agroecosystems; some research has already suggested the favorable effects of conservation tillage practices and organic fertilizers on soil enzyme activities. Tarafdar et al. (1994) found that urease is released from living and disintegrated microbial cells and in the soil, it can exist as an extracellular enzyme absorbed on clay particles or encapsulated in humic complexes and phosphatase activity may originate from the plant roots, and associated mycorrhiza and other fungi, or from bacteria. Mohammadi (2011) found that mineral fertilizers significantly decrease activities of dehydrogenase, phosphatase and urease than in the farm yard manure and compost treatments. Usman et al. (2013) found that a hot arid climate and in an irrigated condition when crop residues were left on the field, the final biomass and grain yield of wheat under no tillage were similar to those obtained under minimum tillage and conventional tillage. The objective of this work was to determine short-term (two season) effects of tillage systems (no tillage, minimum tillage and conventional tillage) and fertilization (organic manures and mineral) on soil quality indicators and wheat grain production, in Burg-El-Arab region, Egypt.

Egypt. J. Soil. Sci. 55, No. 1 (2015) 


\section{Materials and Methods}

\section{Experimental filed}

This study was carried out in Burg El-Arab region. Experiment was arranged in the split plot based on randomized complete block design with three replications. Main plots consisted of no tillage (NT), minimum tillage (MT) (disk harrowing with average depth of $15 \mathrm{~cm}+$ one shallow disk harrowing) and conventional tillage (CT) (moldboard plowing with average depth of $30 \mathrm{~cm}+$ two shallow disks followed by secondary tillage with a soil grubber and harrow for seedbed preparation). Sub-plots were five treatments of supplying fertilizer including F1 Control; F2 $\left(20 \mathrm{~m}^{3}\right.$ farmyard manure Fed $\left.{ }^{-1}\right)$; F3: $15 \mathrm{~m}^{3}$ compost $\mathrm{Fed}^{-1}$; F4, $100 \mathrm{~kg}$ super phosphate (T-P equals $\left.15.5 \%\right)+250 \mathrm{~kg}$ Urea (T-N equals $50 \%)+50 \mathrm{~kg}$ potassium sulphate (T-K equals 48,6\%) $\mathrm{Fed}^{-1}$; F5 mixture of all fertilizers $\left(10 \mathrm{~m}^{3}\right.$ farmyard manure $\mathrm{Fed}^{-1}+5 \mathrm{~m}^{3}$ compost $\mathrm{Fed}^{-1}+50 \mathrm{~kg}$ super phosphate $\mathrm{Fed}^{-1}+50 \mathrm{~kg}$ potassium sulphate $\mathrm{Fed}^{-1}$ ). The values of basal fertilizer were determined according to soil test analyses. The soil analyses, farmyard manure and compost were analyzed for chemical and physical properties (Table 1, a \& b, and Table 2). Farmyard manure, compost and chemical fertilizers were added to plots before sowing wheat. For CT and MT, chemical fertilizer or organic fertilizers was applied and then incorporated with tillage, while for MT treatments, fertilizers were surface applied on the plots. Urea fertilizer was applied equally two times before sowing wheat and before flowering. Wheat seeds were planted on November 14, 2010 and November 21, 2012. Main plot area was of $15 \mathrm{~m} \times 20 \mathrm{~m}$ and spaces between main plots were three meters and 2 meters between blocks. The field was irrigated twice with a 8 10 day interval for the better germination of seeds. The field was also irrigated at stemming and flowering along with fertilization and twice in grain filling.

\section{Soil analysis}

Soil physical and chemical properties according to Black et al. (1962) are shown in Table $1(\mathrm{a}, \mathrm{b})$. Total nitrogen was determined using the Kjeldahl method. Soil microbiological analysis was sampled in wheat plots. Soil samples were collected from crop rhizosphere at flowering stage of wheat growth. Soil was shaken off the roots and the soil that adhered strongly to the roots was carefully brushed from the roots. The samples from each plot were combined, passed through a 2-mm sieve and stored for analysis.

\section{Microbial Biomass (MB)}

Soil MB was determined from samples by the chloroform fumigation extraction method (Wu et al., 1990), organic matter (Bertran \& Andreas, 1994 and El-kouny, 1999).

\section{Soil enzymes activities}

Protease activity was determined according to Kandeler (1996). Acid phosphatase enzyme was determined according to Mandal et al. (2007), urease activity (Nannipieri et al., 1974) and dehydrogenase activity (Serra-Wittling 
et al., 1995). All enzyme activities values were calculated based on oven-dry $\left(105^{\circ} \mathrm{C}\right)$ weight of soil.

TABLE 1-a. Physical characteristics of the studied soil used in this investigation.

\begin{tabular}{|c|c|c|c|c|c|}
\hline \multirow{2}{*}{$\begin{array}{c}\text { Growing } \\
\text { Season }\end{array}$} & \multicolumn{3}{|c|}{$\begin{array}{c}\text { Particle size } \\
\text { distribution }\end{array}$} & \multirow{2}{*}{$\begin{array}{c}\text { Texture } \\
\text { Class }\end{array}$} & $\begin{array}{c}\text { Total } \\
\text { Carbonate, } \\
\text { \% }\end{array}$ \\
\cline { 2 - 4 } & Sand & Silt & clay & & 25.5 \\
\hline $2010 / 2011$ & 85.2 & 10.2 & 4.5 & Sandy silty loam & 23.5 \\
\hline $2011 / 2012$ & 80.2 & 15.1 & 4.7 & Sandy silty loam & \\
\hline
\end{tabular}

TABLE 1-b. Chemical characteristics of the studied soil used in this investigation.

\begin{tabular}{|c|c|c|c|c|c|c|c|c|c|c|c|c|}
\hline \multirow{2}{*}{ 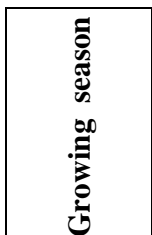 } & \multirow[b]{2}{*}{ 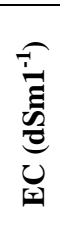 } & \multirow[b]{2}{*}{ 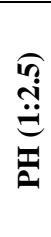 } & \multicolumn{4}{|c|}{ Cations (Meq/L) } & \multicolumn{3}{|c|}{ Anions (Meq/L) } & \multirow[b]{2}{*}{$\sum_{0}^{0}$} & \multirow[b]{2}{*}{ 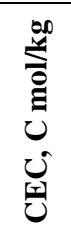 } & \multirow[b]{2}{*}{ 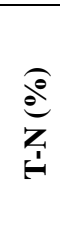 } \\
\hline & & & ${ }^{+} \bar{Z}$ & +4 & 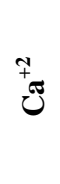 & $\stackrel{7}{+50}^{+\infty}$ & $\underbrace{\prime}$ & $\overline{0}$ & $\overbrace{\mathscr{E}}^{T}$ & & & \\
\hline $2010 / 2011$ & 4.8 & 8.5 & 38 & 1.61 & 6.1 & 2.2 & 4.1 & 34.2 & 2,0 & 1.01 & 12.3 & 0.05 \\
\hline $2011 / 2012$ & 4.1 & 8.3 & 36 & 1.81 & 4.1 & 1.2 & 4.9 & 32.2 & 4.5 & 1.1 & 13.1 & 0.08 \\
\hline
\end{tabular}

TABLE 2. Chemical properties of compost and farmyard manure applied to the soil.

\begin{tabular}{|c|c|c|c|c|c|c|c|c|c|}
\hline \multirow{2}{*}{ 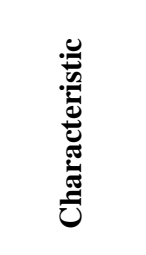 } & 部 & $\begin{array}{l}\mathbf{Z} \\
\dot{1}\end{array}$ & $\frac{9}{4}$ & 告 & $\bar{v}$ & z & \multirow{2}{*}{ 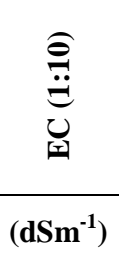 } & \multirow{2}{*}{ 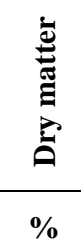 } & \multirow{2}{*}{ 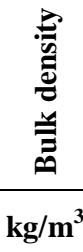 } \\
\hline & & \multicolumn{5}{|c|}{$\%$} & & & \\
\hline Compost & 6.61 & 1.8 & 1.12 & 0.49 & 0.18 & 0.19 & 4.25 & 84.5 & 650 \\
\hline $\begin{array}{c}\text { Farmyard } \\
\text { manure }\end{array}$ & 7.76 & 0.67 & 0.47 & 0.25 & 0.2 & 0.21 & 5.9 & 65.8 & 450 \\
\hline
\end{tabular}

Statistical analysis

The statistical analysis was carried out using the statistical analysis system (SAS Institute, 2003) for windows.

\section{Results and Discussion}

The results of this research work were demonstrated in figures and tables.

\section{Grain Yield}

Wheat grain yield as shown in Fig. 1 was affected by different fertilization treatments. Fertilizers comparison showed that F5 treatment was significantly different from other treatments.

Egypt. J. Soil. Sci. 55, No. 1 (2015) 


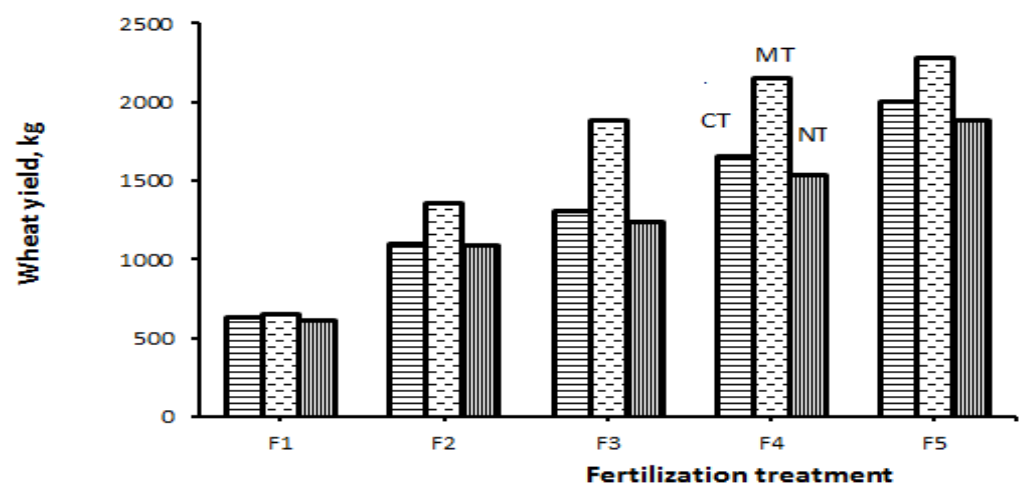

Fig. 1. Effect fertilization on wheat grain yield under 3 tillge systems.

For rationalization of this difference it could be stated that parallel to meeting plant need to phosphorus and nitrogen, adding compost and farmyard manure to soil can provide micro elements for plant; also, it seems that organic fertilizers improving soil structure and optimizing root growth conditions by providing organic matter and nutrients. Tillage systems significantly affected grain yield; the highest rate of grain yield was produced in MT that was statistically greater than which in CT and NT systems (Fig. 2). CT caused an average reduction of about $17 \%$ in grain yield as compared with MT, while it showed increasing of about $4 \%$ than NT. Schillinger (2005) found that NT caused lower production of wheat in comparison with CT, in part because of less water in the seed zone compared with CT during early plant development, while Hemmat et al. (2006); Peltzer et al. (2009) and Haj Abbasi et al. (2000) reported that the main reason of wheat yield reduction in NT is the reduction in plant density.

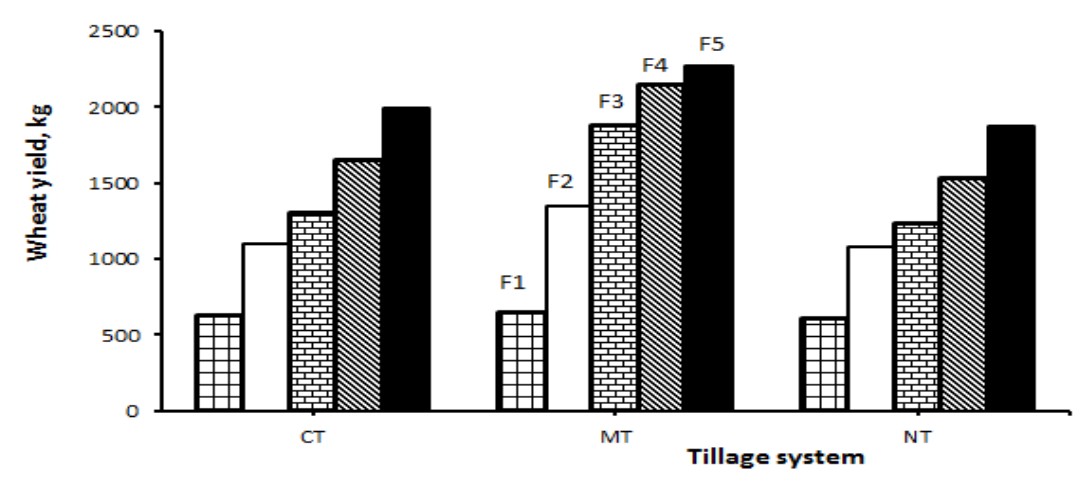

Fig. 2. Effect of tillage on wheat grain yield under fertilization treatments.

The most probable cause of erratic stand establishment for no-till wheat treatment was poor soil seed contact associated with the use of the drill for 
seeding into a layer of crop residue (Karlen et al., 1987). On the other hand, Tarkalsona et al. (2006) reported that application of NT system in a long term period led to indicative improvement in wheat productivity in comparison with CT system (Abdel-Satter et al., 2011), therefore using MT is more favored by farmers (Shams Abadi et al., 2007) and leads to increase wheat production.

\section{Soil Microbial Biomass (MB)}

Through the statistical analysis of results, we conclude that there were significant $(\mathrm{p}<0.05)$ differences between tillage systems and fertilization treatments. Addition of mixture fertilizer (F5) significantly $(p<0.05)$ increased soil $\mathrm{MB}$ in comparison with the other treatments as shown in Fig. 3. No significant difference between compost (F2) and farm yard manure (F3), but they showed significant differences comparing to mineral fertilizer (F4) or control (F1). The higher values of MB in the soil treated with F5, F2, and F3, could be due to greater amounts of biological materials such as mineralizable nitrogen. Application of treatment F5 provides a balanced supply of element nutrients and soil organic matter (Mohammadi, 2011). NT and MT increased soil MB comparing with CT, Generally NT and MT increase soil MB in all fertilization treatments. fertilization treatment F5 showed highly significant in soil MB comparing with the other fertilization treatments. Madejon et al. (2007) observed that minimum tillage increased soil MB.

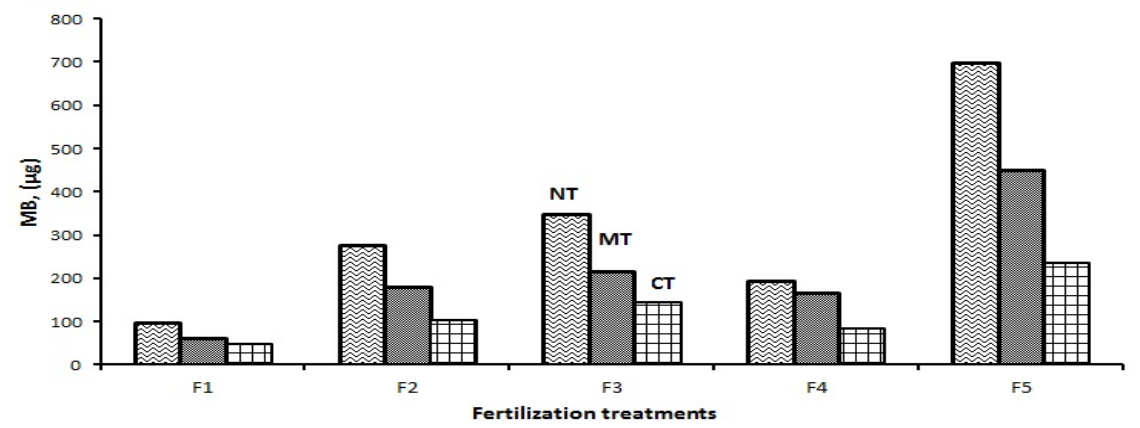

Fig. 3. Effect of fertilization treatments and tillage systems on soil MB.

Soil enzymes activities

Generally, results of statistical analysis showed that there were significant differences in the activity levels of enzymes with fertilization treatments.

\section{Urease enzyme activity}

Results of urease are shown in Fig. 4. Urease enzyme activity was significant in each of fertilization treatments, tillage systems and in the interaction between them. Urease activity showed a significant decrease with mineral fertilizer treatment F4 compared with manure F2, compost F3 and mixture of fertilizers F5. Farmyard manure showed a significant increase in urease activity compared 
with all fertilization treatments. Applications of nitrogen fertilizers significantly decrease urease activity while addition of organic manure increased its activity. Mohammadi (2011) concluded that is because the nitrogen fertilizers used in the experiments contained $\mathrm{NH} 4+$ and that the reaction products of urease being $\mathrm{NH} 4+$, microbial induction of urease activity had been inhibited. The effect of organic amendments on enzyme activities is probably a combined effect of a higher degree of stabilization of enzymes to humic substances and an increase in microbial biomass with increased soil carbon concentration (Martens et al., 1992 and Giusquian et al., 1994). Tillage systems also showed significant effect on urease activity. A significant increase in the activity of urease was realized with no tillage treatment, and with farmyard manure F2 + no tillage system NT.

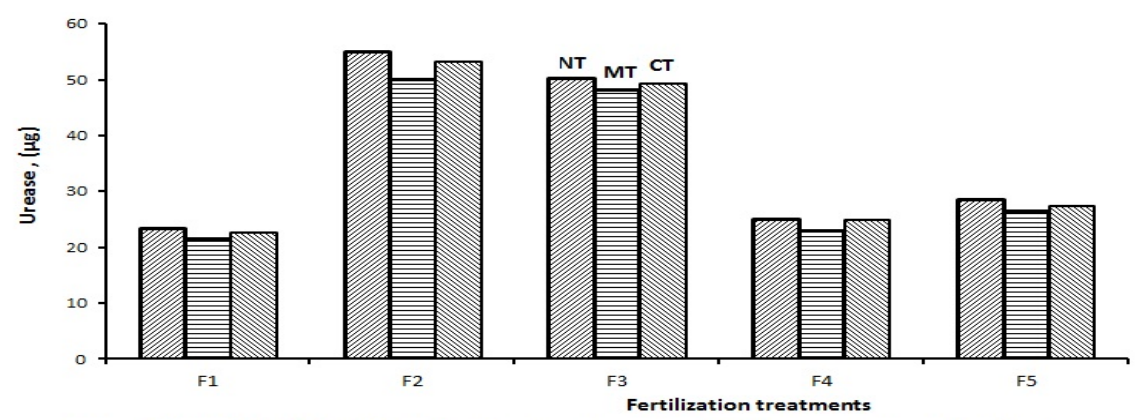

Fig. 4. Effect of fertilization treatments and tillage systems on urease.

\section{Phosphatase activity}

Figure 5 shows the effect of fertilization treatments on acid phosphatase activity under three tillage systems. Acid phosphatase generally increased with compost applications. There were no differences in phosphatase activity between the compost treatment F3 and the farm yard treatments F2 as well as the mixture F5. The acid phosphatase in the F1 treatment was significantly lower than in the other treatments.

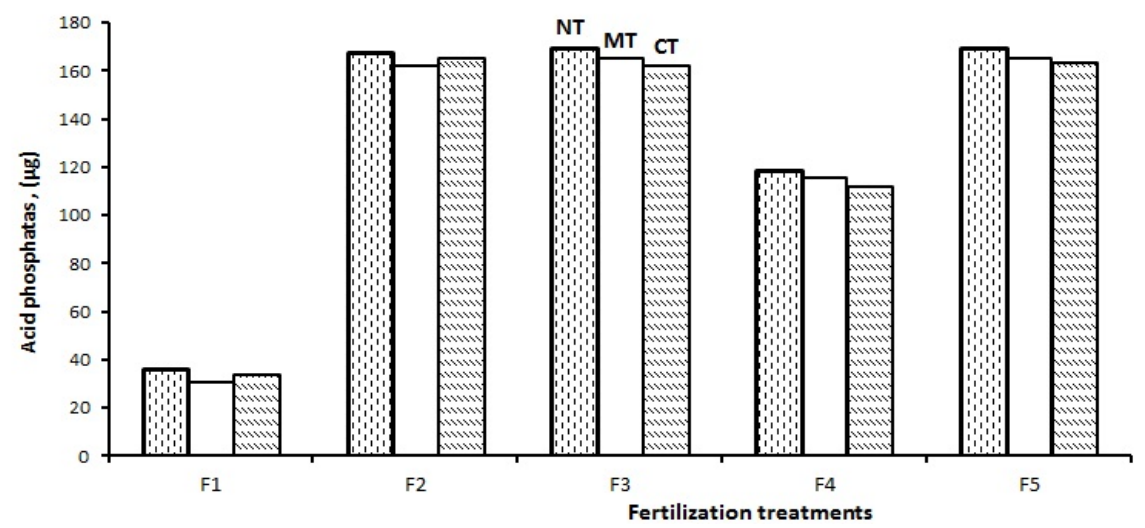

Fig. 5. Effect of fertilization treatments and tillage systems on acid phosphatase.

Egypt. J. Soil. Sci. 55, No. 1 (2015) 
There were significant differences between the interaction effect between tillage and fertilization on acid phosphatase activity, MT with F5, F3 and F2 treatments showed the higher significant difference. Increased phosphatase activity could be responsible for hydrolysis of organically bound phosphate into free ions, which were taken up by plants. Tarafdar et al. (1994) reported that plants can utilize organic $\mathrm{P}$ fractions from the soil by phosphatase activity enriched in the soil- root interface. The observed increase in enzymatic activities due to organic fertilizers amendments are in accordance with previous studies. Martens et al. (1992) reported that addition of the organic matter maintained high levels of phosphatase activity in soil during a long term study. Giusquian et al. (1994) reported that phosphatase activities increased when compost was added at rates of up to $37 \mathrm{t} \mathrm{Fed}^{-1}$ and the phosphatases continued to show a linear increase with compost rates of up to $112 \mathrm{t} \mathrm{Fed}^{-1}$ in a field experiment. Results indicated that NT system showed statistically significant $(p<0.05)$ differences in the acid phosphatase enzyme activity in the soil comparing with MT and CT. The activity of acid phosphatase tended to be higher in the NT treatment compared to the MT and CT treatments. Jin et al. (2009) reported the positive effects of conservation tillage practices on soil enzyme activities. The generally higher enzyme activities in NT mainly resulted from the larger water availability in the plots rather than the better soil fertilities.

\section{Dehydrogenase activity}

Dehydrogenase activity as affected by fertilization treatments under three tillage systems was shown in Fig. 6. Generally, dehydrogenase activity was significantly lower in the treatments contain mineral fertilizers. Compost F2 and farm yard manure F3 applications increased dehydrogenase activity as shown in Fig. 6. Stronger dehydrogenase activity in compost applied plots may be due to higher organic matter content (Wlodarczyk et al., 2002). Marinari et al. (2000) reported that a higher level of dehydrogenase activity was observed in soil treated with compost and farmyard manure compared to soil treated with mineral fertilizer. Application of compost caused a significant increase in dehydrogenase activity (Martens et al., 1992).

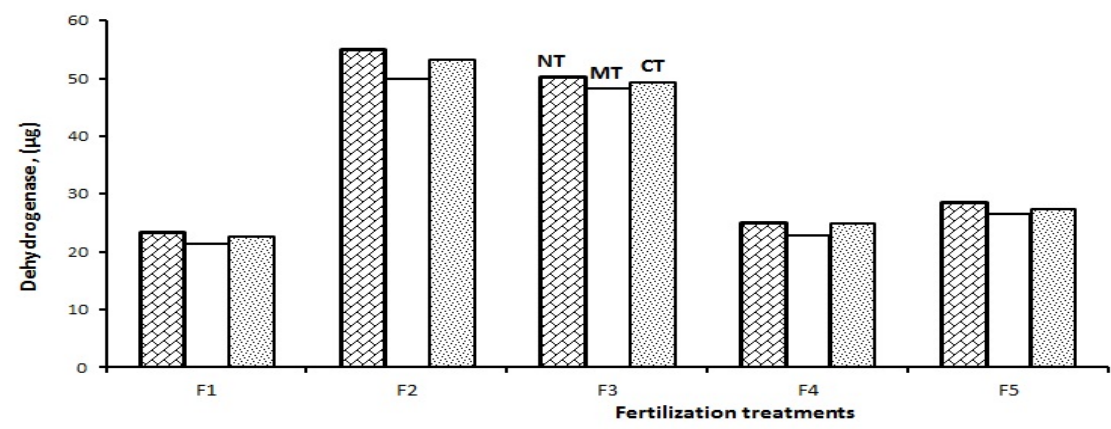

Fig. 6. Effect of fertilization treatments and tillage systems on dehydrogenase.

Egypt. J. Soil. Sci. 55, No. 1 (2015) 
These results were similar to our result that dehydrogenase in rhizosphere soil of F3 treatments was more than 2 times higher than that of mineral fertilizer F4 treatment, also similar with the findings of Mohammadi (2011) that average three times higher than that of F4 treatment. In addition, the highest organic matter levels in the compost treatments may provide a more favorable environment for the accumulation of enzymes in the soil matrix, since soil organic constituents are thought to be important in forming stable complexes with free enzymes. The dehydrogenase activities in the compost F4 treatment were significantly lower than in the farm yard manure F2 and compost F3. The dehydrogenase activity under NT F2 treatment showed higher values than all treatments. F2 treatment had a significant difference with other treatments.

\section{Protease activity}

The results showed statistically significant $(\mathrm{p}<0.05)$ differences in the level of protease activity in the soil between various methods of tillage and fertilization as well as the interaction between them. The activity of protease tended to be higher in the NT treatment compared to the MT and CT treatments. Fertilization F5 and F3 treatments showed high significant comparing to the others.

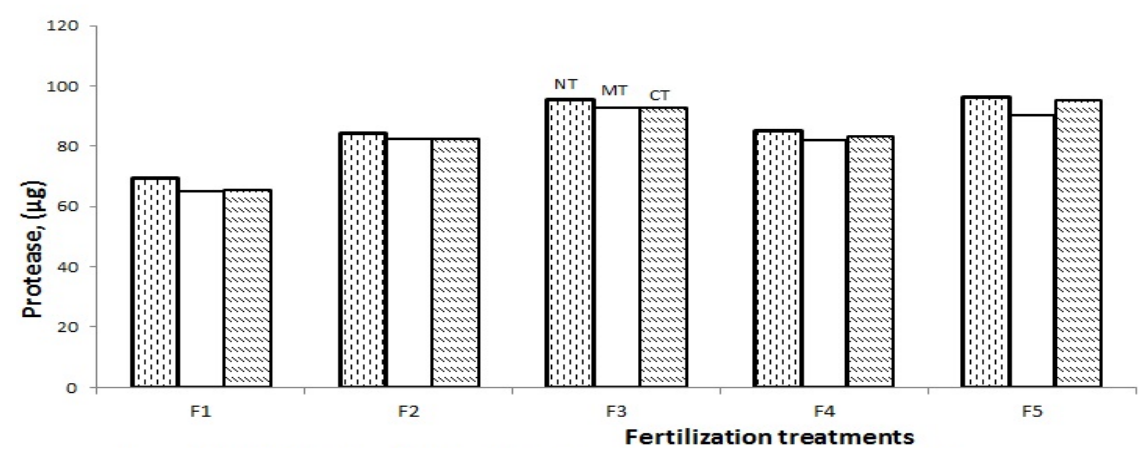

Fig. 7. Effect of fertilization treatments and tillage systems on protease.

\section{Conclusion}

The present study revealed that the soil microbial biomass and enzymes activity were influenced by fertilization and tillage in wheat productivity. The results demonstrate that microbial biomass and soil enzymes activity are sensitive in discriminating between organic manure and mineral fertilizer applications on a short-term. Consistent distinctions in enzyme activities were observed between different no tillage and minimum tillage. The yield of wheat was affected by soil fertility amendments and tillage systems in this study. Organic manure increased yield, soil physical properties, soil fertility, beneficial microbial populations and activity of enzymes. 


\section{References}

Abdel-Satter, M. El-Tanany and El-Kouny, H. M. (2011) Reducing mineral fertilizers by using organic manure to improve Washington navel orange productivity and sandy soil characteristics.

Angers, D.A., N'dayegamiye, A. and Côté, D. (1993) Tillage-induced differences in organic matter of particle-size fractions and microbial biomass. Soil Sci. Soc. Am. J. 57, 512-516.

Biederbeck, V.O.M., Zentner, R.P. and Campbell, C.A. (2005) Soil microbial populations and activities as influenced by legume green fallow in a semiarid climate. Soil Biology and Biochemistry, 37, 1775-1784.

Black, C. A. (1965) "Methods of Soil Analysis". Parts 1 and 2. Amer. Soc. Agron. Inc., Madison, Wisconsin, USA.

Carter, M.R. (1991) The influence of tillage on the proportion of organic carbon and nitrogen in the microbial biomass of medium-textured soils in a humid climate. Biol. Fertility Soils, 11, 135-139.

Carter, M.R. (2002) Soil quality for sustainable land management: Organic matter and aggregation interactions that maintain soil function. Agron. J. 94, 38-47.

Chander, K., Goyal, S., Nandal, D.P. and Kapoor, K.K. (1998) Soil organic matter, microbial biomass and enzyme activities in a tropical agroforestry system. Biology and Fertility of Soils, 27, 168-172.

Dick, R. P. (1992) Areview long-term effect of agricultural systems on soil biochemical and microbial parameters. Agric. Ecosyst. Environ. 40, 25.

Doran, J.W. (1987) Microbial biomass and mineralizable nitrogen distributions in notillage and plowed soils. Biol. Fertil. Soils, 5, 68-75.

El-Kouny, H.M. (1999) Evaluation of compost production and its properties with special reference to compost extract. Ph.D. Thesis, Fac. Agric. Alex. Univ., Egypt.

El-Kouny, H.M., El-Assar, A.M. and Mohamed, S.G. (2004) Effectiveness of natural organic amendments. biologically activated composted and mineral fertilization sources of potassium in improving soil properties and productivity of " Zaghloul cv ." date pal in calcareous soil. Assiut J. Agric. Sci., 25, 2.

Fan, M., Jiang, R., Liu, X., Zhang, F., Lu, S., Zeng, X. and Christie, P. (2005) Interactions between non-flooded mulching cultivation and varying nitrogen inputs in rice-wheat rotations. Field Crops Research, Vol. 91, No. 2-3, 2005, pp.

FAO (2005) "The Importance of Soil Organic Matter". Food and Agriculture Organization of the United Nations.

Egypt. J. Soil. Sci. 55, No. 1 (2015) 
Filizola, H.F., Valarini, P. J. and Tokeshi, H. (1998) Environmental impact of irrigated conventional farming system. Test of biodynamical farming system In: "World Congress of Soil Science". Summaries. Montpellier, Guaira, Sao Paulo State, Brazil.

Giusquiani, P.L., Gigliotti, G. and Businelli, D. (1994) Long-term effects of heavy metals from composted municipal waste on some enzyme activities in a cultivated soil. Biology and Fertility of Soils, 17, 257-262.

Guarda, G., Padovan, S. and Delogu, G. (2004) Grain yield, nitrogen-use efficiency and baking quality of old and modern italian bread-wheat cultivars grown at different nitrogen levels. European Journal of Agronomy, Vol. 21, No. 2, 2004, pp. 181-192.

Haj Abbasi, M.A. and Hemmat, A. (2000) Tillage impacts on aggregate stability and crop productivity in clay-loam soil in central Iran. Soil and Tillage. Res., 56, 205-212.

Hemmat, H. and Eskandari, I. (2006) Dry land winter wheat response to conservation tillage in a continuous cropping system in north western Iran. Soil and Tillage. Res., 86, 99-109.

Jin, K., Sleutel, S., Buchan, D., De Neve, S., Cai, D.X., Gabriels, D., and Jin, J.Y. (2009) Changes of soil enzyme activities under different tillage practices in the Chinese Loess Plateau. Soil and Tillage Res., 104, 115-120.

Kandeler, E. (1996) Protease Activity. In: Schinner F., Ohlinger R., Kandeler E., Margesin R. (Ed.) Methods in Soil Biology, Springer, Berlin/Heidelberg/New York) pp. $165-168$.

Kandeler, E., Tscherko, D. and Spiegel, H. (1999) Long-term monitoring of microbial biomass, $\mathrm{N}$ mineralisation and enzyme activities of a Chernozem under different tillage management. Biology and Fertility of Soils, 28, 343-351.

Karlen, D.L. and Gooden, D.T. (1987) Tillage systems for wheat production in the southeastern coastal plains. Agronomy J., 79, 582-587

Lundquist, E.J., Jackson, L.E., Scow, K.M. and Hsu, C. (1999) Changes in microbial biomass and community composition and soil carbon and nitrogen pools after incorporation of rye into three California agricultural soils. Soil Biology and Biochemistry, 31, 221-236.

Lynch, J.M. (1983) Soil Biotechnology. Blackwell Oxford, pp. 191.

Lal, R. (2002) Soil carbon dynamics in cropland and rangeland. Environmental Pollution, 116, 353-362.

Malhi, S. S., Grant, C. A., Johnston, A. M. and Gill, K. S. (2001) Nitrogen fertilization and management for No-Till Ce- real production in the Canadian Great Plains: A review," Soil and Tillage Research, Vol. 60, No. 3-4, pp. 101-122.

Mandal, A., Patra, A.K., Singh, D., Swarup, A. and Masto, R.E. (2007) Effect of longterm application of manure and fertilizer on biological and biochemical activities in soil during crop development stages. Bioresource Technol., 98, 3585-3592. 
Martens, D.A., Johanson, J.B. and Frankenberger, J.W.T. (1992) Production and persistence of soil enzymes with repeated addition of organic residues. Soil Sci., 153, 53-61.

Marinari, S., Masciandaro, G., Ceccanti, B. and Grego, S. (2000) Influence of organic and mineral fertilizers on soil biological and physical properties Bioresoruce Technol., 72, 9-17.

Nannipieri, P., Ceccanti, B., Cervelli, S. and Sequi, P. (1974) Use of $0.1 \mathrm{M}$ pyrophosphate to extract urease from a podzol. Soil Biology and Biochemistry, 6, 359362 .

Mohammadi, K. (2011) Soil microbial activity and biomass as influenced by tillage and fertilization in wheat production. American-Eurasian J. Agric. \& Environ. Sci., 10 (3), 330-337.

Nishio, M. and Kusano, S. (1980) Fluctuation patterns of microbial numbers in soil applied with compost Soil Science. Plant Nutrition, 26, 581-593.

Peltzer, S.C., Hashem, A.I.A., Osten, B.V.A., Gupta, C.M.L., Diggle, D.A.J., Riethmuller, E.G.P., Douglas, F.A., Moore, G.L.M. and Koetz, H. (2009) Weed management in wide-row cropping systems: a review of current practices and risks for Australian farming systems. Crop and Pasture Sci., 60, 395-406.

Rice, P.J., McConnell, L.L., Heighton, L.P., Sadeghi, A.M., Isensee, A.R., Teasdale, J.R., Abdul-Baki, A.A., Harman-Fetcho, J.A. and Hapeman, C.J. (2001) Runoff loss of pesticides and soil: a comparison between vegetative mulch and plastic mulch in vegetable production systems. J. Environment Quality, 30, 1808- 1821

SAS Institute (2003) The SAS system for windows. Release 9.1, SAS Inst, Cary, N.C.,

Shams Abadi, H.A. and Rafiee, S. (2007) Study on the effect of tillage practices and different seed densities on yield of rainfed wheat. Iranian J. Agricultural Science and Natural Reso., 13, 95-102

Schillinger, W.F. (2005) Tillage method and sowing rate relations for dryland spring wheat, barley and oat. Crop Sci., 45, 2636-2643.

Tarafdar, J.C. and Marschner, H. (1994) Phosphatase activity in the rhizosphere and hyphosphere of VA mycorrhizal wheat supplied with inorganic and organic phosphorus. Soil Biology and Biochemistry, 26, 387-395.

Tarkalsona, D.D., Hergertb, G.W. and Cassman, K.G. (2006) Long-term effects of tillage on soil chemical properties and grain yields of a dryland winter wheat sorghum-corn-fallow rotation in the Great Plains. Agronomy J., 98, 26-33

Usman, K., Khan, E. A., Khan, N., r Khan, M. A., Ghulam, S, Khan, S. and Baloch, J. (2013) Effect of tillage and nitrogen on wheat production, economics, and soil fertility in rice-wheat cropping system. American Journal of Plant Sciences, 4, 17-25. 
Wlodarczyk, T., Stepniewski, W. and Brzezinska, M. (2002) Dehydrogenase activity, redox potential and emissions of carbon dioxide and nitrous oxide from Cambisols under flooding conditions. Biology and Fertility of Soils, 36, 200-206.

Wu, J., Joergensen, R.G., Pommerening, B., Chaussod, R., and Brookes, P.C. (1990) Measurement of soil microbial biomass $\mathrm{C}$ by fumigation extraction an automated procedure. Soil Biology and Biochemistry, 22, 1167-1169.

(Received 17/12/2013; accepted 15/1/2015)

\section{تاثير الحرث و التسـميد على انتاجية القمـح و على انزيمـات التربـة

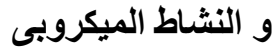

حسين أحمد أحمد الصورى ، أحمد ابراهيم محمود شومان " ، سعد عبد الصمد الصدان

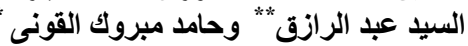

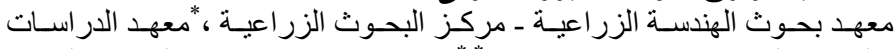

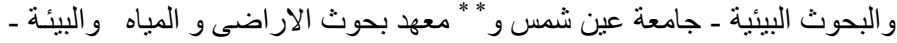

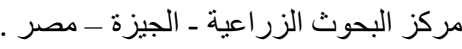

أجريت در اسة لتحديد أفضل نظام للتسميد والحرث لإنتاج القــح. أجريت التجارب

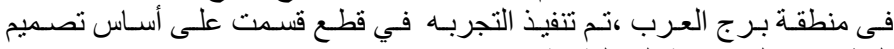

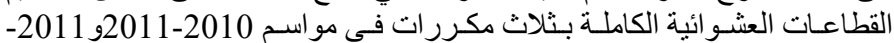

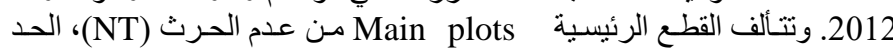

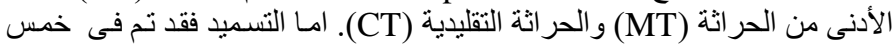

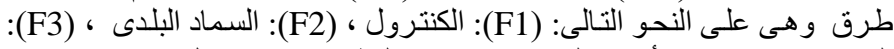

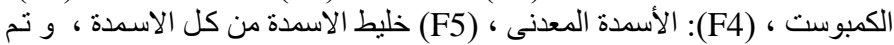

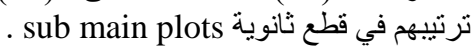

اوضحت النتائج انه قد تم إنتاج أعلى معدل لمحصول حبوب القمح تحت نظسام

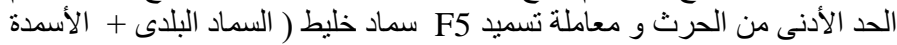

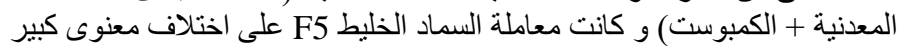

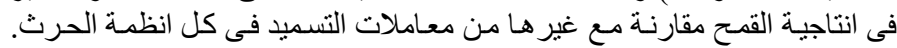

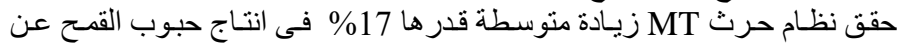

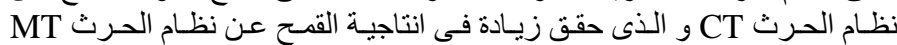

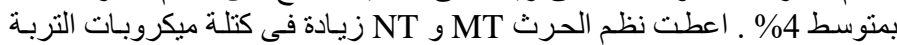

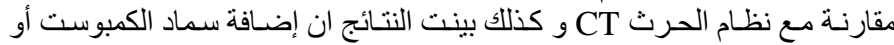

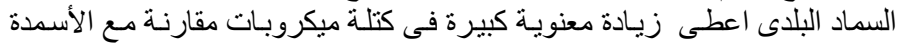

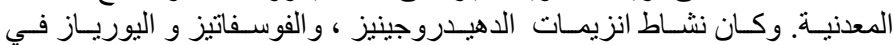

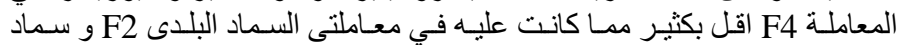

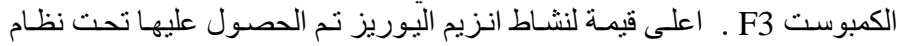

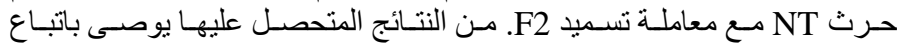

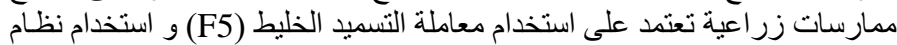

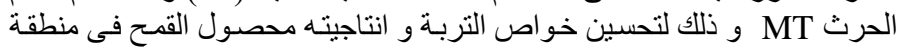

$$
\text { الدراسه. }
$$

